\title{
Scottish rehabilitation services: eight year follow-up
}

\author{
Robin G. MCCreadie, Director of Clinical Research and Consultant Psychiatrist; \\ Douglas J. Williamson, Research Registrar; and LesLeY J. ROBERTSON, formerly \\ Research Registrar, Crichton Royal Hospital, Dumfries DG1 4TG
}

A survey of Scottish psychiatric rehabilitation and support services, carried out in 1983 (McCreadie et al, 1985), found that although there were wide between-hospital differences, the National Health Service in Scotland was making considerable efforts to provide services for the long-term mentally ill. However, services provided by local authorities were seriously deficient.

The move away from in-patient care for the longterm mentally ill has continued in recent years. If the "community" (which is often a hard pressed relative) is to accept such patients then there must be available a range of rehabilitation and support services. "The successful implementation of community care policy depends crucially on the availability of, and ease of access to, adequate and appropriate services in the community" (Her Majesty's Stationery Office, 1989). It is envisaged that community services should be provided by the NHS, local authorities, voluntary agencies and the independent sector.

The present study has two principal aims. Firstly, it describes what changes have taken place in Scotland over the eight years since the first survey. Secondly, the findings will act as a baseline for future examination of the working of the NHS and Community Care Act 1990.

\section{The study}

Scottish psychiatric hospitals and units in general hospitals were invited to participate in the survey. In each hospital and unit which responded a psychiatrist, after discussion with appropriate professionals, described on the census date (1.2.91) rehabilitation and support services in the hospital's catchment area for adult psychiatric patients who had first had contact with psychiatric services between ages 18-64 years. In this way services for the elderly with dementia were excluded. Facilities asked about were those widely accepted as useful in the management of patients with longstanding mental illness,

Hospital co-ordinators: Drs N. Ali, D. Ball, J. K. Binns, T. V. K. Chandrasekhar, I. Clark, R. J. Craig, G. T. Crocket, P. Dick, J. M. Dingwall, A. Drayson, J. Flowerdew, J. D. Hendry, D. Jones, P. Kershaw, A. V. P. Mackay, R. G. McCreadie, Y. A. Morrison, J. Murphy, A. Scott, J. L. Waddell, A. Yellowlees. and included NHS staffing and facilities, NHS and non-NHS employment opportunities, local authority facilities, facilities provided by voluntary organisations, and housing associations. Consultants were also asked to comment on the main strengths and weaknesses of rehabilitation services in the hospital's catchment area.

\section{Findings}

Psychiatric hospitals and general hospital psychiatric units with a combined catchment population in 1991 of 3.86 million, $75 \%$ of the Scottish total of 5.13 million, responded to the questionnaire. The hospitals serve a wide range of urban, rural and mixed catchment areas. There were in all 21 catchment areas, 17 of which participated in both the 1983 and 1991 surveys.

\section{Staffing, accommodation and work opportunities}

In order to compare 1983 with 1991, the following results pertain only to the 17 catchment areas which took part in both surveys. Numerical results have been converted to rates per 100,000 of the general population.

There has been a substantial increase in the total number of consultants, trained hospital based nurses, community psychiatric nurses, occupational therapists, occupational therapy technicians and clinical psychologists (Table I). Non-consultant medical staff, untrained nurses and occupational therapy aides did not increase their numbers significantly. Table I also shows the proportion of time professionals spent in the in-patient rehabilitation units and day hospitals, separately and combined. Only two groups of staff in 1991 were spending more time in such facilities - trained nurses and occupational therapists. The increase was to be found in the day hospital. Trained occupational therapists gave more of their time $(30 \%)$ than any other group to rehabilitation and day services.

There has been a substantial reduction in the total number of staffed beds in Scottish psychiatric hospitals (Table II). There has been a corresponding fall in the numbers of beds in long term non-geriatric or continuing care wards, defined as wards for patients 
TABLE I

Staffing: group rates per 100,000 general population

\begin{tabular}{|c|c|c|c|c|c|c|c|c|c|c|}
\hline & \multicolumn{4}{|c|}{ Total } & \multicolumn{2}{|c|}{$\begin{array}{c}\text { Rehabilitation } \\
\text { Unit }\end{array}$} & \multicolumn{2}{|c|}{$\begin{array}{c}\text { Day } \\
\text { hospitals }\end{array}$} & \multicolumn{2}{|c|}{$\begin{array}{l}\text { Rehabilitation } \\
\text { unit and day } \\
\text { hospitals }\end{array}$} \\
\hline & $\begin{array}{l}198 \\
\text { mean }\end{array}$ & 3 s.d. & $\begin{array}{l}199 \\
\text { mean }\end{array}$ & 1 s.d. & $\begin{array}{c}1983 \\
\text { mean }\end{array}$ & $\begin{array}{l}1991 \\
\text { mean }\end{array}$ & $\begin{array}{c}1983 \\
\text { mean }\end{array}$ & $\begin{array}{l}1991 \\
\text { mean }\end{array}$ & $\begin{array}{l}1983 \\
\text { mean }\end{array}$ & $\begin{array}{l}1991 \\
\text { mean }\end{array}$ \\
\hline \multicolumn{11}{|l|}{$\begin{array}{l}\text { Staff numbers } \\
\text { (whole time equivalents) }\end{array}$} \\
\hline Consultants & $3.4^{*}$ & 0.8 & $4.4^{*}$ & 0.8 & 0.2 & 0.1 & 0.2 & 0.3 & 0.4 & 0.4 \\
\hline Other medical staff & 5.7 & 1.9 & 6.6 & 2.2 & 0.4 & 0.2 & 0.4 & 0.5 & 0.8 & 0.7 \\
\hline Trained nurses & $101.1^{* *}$ & 32.5 & $122.8^{* *}$ & 28.7 & 5.0 & 7.8 & $1.5^{* * *}$ & $3.8^{* * *}$ & 6.5 & 11.6 \\
\hline Untrained nurses & 75.5 & 32.7 & 82.6 & 19.1 & 2.8 & 2.1 & 0.2 & 0.7 & 3.0 & 2.8 \\
\hline $\begin{array}{l}\text { Community psychiatric } \\
\text { nurses }\end{array}$ & $3.5^{*}$ & 1.9 & $7.9^{*}$ & 3.1 & - & - & - & - & - & - \\
\hline $\begin{array}{l}\text { Trained occupational } \\
\text { therapists }\end{array}$ & $2.0^{*}$ & 1.7 & $4.5^{*}$ & 1.6 & 0.3 & 0.4 & $0.3^{* * *}$ & $1.0^{* * *}$ & 0.6 & 1.4 \\
\hline OT aides & 2.4 & 1.5 & 2.5 & 1.6 & 0.2 & 0.1 & 0.5 & 0.5 & 0.7 & 0.6 \\
\hline OT technicians & $0.6^{* * *}$ & 1.0 & $1.6^{* * *}$ & 1.3 & 0.3 & 0.0 & 0.1 & 0.1 & 0.4 & 0.1 \\
\hline Clinical psychologists & $1.6+$ & 1.6 & $2.5 \dagger$ & 1.7 & 0.1 & 0.2 & 0.1 & 0.1 & 0.2 & 0.3 \\
\hline Trained social workers & 2.7 & 1.2 & 3.4 & 1.4 & 0.2 & 0.2 & 0.2 & 0.2 & 0.4 & 0.4 \\
\hline
\end{tabular}

${ }^{*} P<0.001 ;{ }^{* *} P<0.002 ;{ }^{* *} P<0.005 ; \dagger P<0.01$.

TABLE II

Accommodation: group rates per 100,000 general population

$1983 \quad 1991$

mean s.d. mean s.d.

\begin{tabular}{lcccc}
\hline $\begin{array}{l}N H S \\
\text { Total staffed beds }\end{array}$ & $317^{* *}$ & 87 & $273^{* *}$ & 57 \\
$\begin{array}{l}\text { Long term non-geriatric } \\
\text { beds }\end{array}$ & 116 & 66 & 80 & 41 \\
$\begin{array}{l}\text { Rehabilitation beds } \\
\begin{array}{l}\text { Selfcare/hospital } \\
\text { hostel places }\end{array}\end{array}$ & $26 \dagger$ & 29 & $11 \dagger$ & 6 \\
$\begin{array}{l}\text { Hospital based day } \\
\text { hospital places }\end{array}$ & 15 & 20 & 19 & 26 \\
$\begin{array}{l}\text { Community based day } \\
\text { hospital places }\end{array}$ & 9 & 12 & 15 & 14 \\
$\begin{array}{l}\text { Non- } N H S \\
\text { Local authority hostel }\end{array}$ & 7 & 16 & 1 & 3 \\
$\begin{array}{c}\text { places } \\
\text { Voluntary organisation } \\
\text { hostel places }\end{array}$ & $1 * * *$ & 3 & $11^{* * *}$ & 16 \\
$\begin{array}{l}\text { Sheltered housing } \\
\text { places }\end{array}$ & $0.3 *$ & 0.9 & $6.8^{*}$ & 8.3 \\
$\begin{array}{l}\text { Group home places } \\
\text { Local authority day }\end{array}$ & $11^{*}$ & 9 & $6 *$ & 6 \\
$\begin{array}{c}\text { care places } \\
\text { Voluntary organisation } \\
\text { day care places }\end{array}$ & 0.6 & 1.8 & 0.8 & 1.6 \\
\hline
\end{tabular}

${ }^{*} P<0.01 ;{ }^{* *} P<0.02 ;{ }^{* *} P<0.03 ; \dagger P<0.05$. originally admitted to long term care when under 65 years of age; and in the numbers of beds in rehabilitation units, defined as an in-patient unit, which is usually small (10-20 places) and accepts patients from other wards or the community for assessment and treatment. This fall in the numbers of in-patient beds has been accompanied by a rise in hospital and community based day hospital places. However, by 1991 still only 12 of $17(70 \%)$ catchment areas had day places provided by the NHS.

The number of places in local authority hostels and groups homes fell over the eight years. This has been accompanied by a substantial increase in places in hostels run by voluntary organisations and in sheltered housing. The number of places in local authority day centres has remained virtually unchanged, while the number of places in day centres run by voluntary organisations has risen. When longterm non-geriatric beds are excluded, the NHS in Scotland in 1991 was providing 14 in-patient and 34 day-patient places per 100,000 of the general population; the corresponding figures for non-NHS organisations were 25 and 17 . Recommendations by the Department of Health and Social Security in England (1975) were 4-6 hostel places per 100,000 for short term care and rehabilitation, and 15-24 places for long term accommodation, to include staffed houses, unstaffed accommodation and supervised lodgings. DHSS recommendations for non-NHS day centres were 60 places per 100,000 . 
There has been a substantial fall over the eight years in the number of places in hospital based industrial therapy units, from a mean of 45 places $/ 100,000$ general population to 23 places. In 1983, 15 of 17 catchment areas had a hospital based unit; by 1991 the number had fallen to nine. The fall in industrial therapy places has not been matched by an increase in NHS community workshops (only one was identified in Scotland) or non-NHS sheltered workshops. However, eight of the 17 catchment areas in 1991 had garden projects sponsored by the Scottish Association for Mental Health, a new development since 1983.

\section{Other findings}

The following results apply to all 21 services. Nineteen hospitals had a consultant with a special interest in rehabilitation who spent on average 3.7 sessions per week in this area (range 0.7 to 9 sessions). The recommendations of the Social, Community and Rehabilitation Section of the Royal College of Psychiatrists is one session/week/30,000 general population (Dr D. G. Fowlie, personal communication). Ten services had NHS home support over and above that supplied by community psychiatric nurses; for example, six encouraged staff based in in-patient units to visit patients at home and four had a rudimentary family intervention service. Six services had special arrangements for following up vulnerable patients in the community, for example, a computerised register. The strength in the hospital's catchment area mentioned most often was good coordination between different agencies; the weakness the lack of employment facilities.

\section{Comment}

There is little doubt that between 1983 and 1991 there has been a substantial increase in professional staff in psychiatric services within the National Health Service in Scotland. The results suggest, however, that it is only more trained nurses and occupational therapists that are to be found in day hospitals. Medical staff, untrained nurses and occupational therapists, psychologists and social workers are devoting no more time in 1991 to rehabilitation facilities than they were in 1983. Trained occupational therapists remain the most committed to NHS rehabilitation services. The number of inpatient beds in Scottish hospitals has fallen over the eight years. This has not been accompanied by an expansion of local authority services; rather, they have contracted. The most striking change has been the increase in hostels opened by voluntary organisations, and in sheltered housing for the mentally ill, both of which were virtually non-existent in 1983 . The target suggested for non-NHS accommodation by the Department of Health and Social Security in England (1975) has been reached in Scotland.

Also, although NHS day hospitals in 1991 provide most places for the mentally ill, the biggest change over the eight years has been the increase in the number of places provided by the voluntary sector. Once again local authorities are noticeable by their absence. However, the increase in non-NHS day places in Scotland is still far short of the target suggested by the Department of Health and Social Security in England (1975).

Adequate rehabilitation services should provide occupation; work is an important part of most people's day. However, over the eight years there has been a substantial reduction in the number of places in hospital based industrial therapy units. This is no doubt due in part to the ageing of the inpatient population, and the consequent reduction in numbers fit to attend industrial therapy. It may also be that in the 1980 s industrial therapy units were no longer considered appropriate because of the diminishing chance of many patients ever to compete for a job in the open market. The reduction in hospital based work has not been matched by an increase in community based workshops; such facilities would be used especially by daypatients.

Rehabilitation services are increasingly supporting people scattered widely throughout the community. In-patient and day-patient services therefore are not enough. However, less than half the catchment areas had home support over and above that supplied by community psychiatric nurses, and less than a third had special arrangements such as a computerised register for following up vulnerable patients in the community. Unless individual care plan programmes (Scottish Office, 1991; Royal College of Psychiatrists, 1991) improve matters, it is likely that increasing numbers of the long term mentally ill in Scotland will fall through the 'net' of 'community care'.

We conclude that the most striking change in the development of rehabilitation and after care services in Scotland over the past eight years has been the marked increase in services provided by the voluntary sector. Local authorities are noticeable by their absence. A glaring deficit is the opportunity for sheltered work.

\section{Acknowledgements}

This study was carried out under the auspices of the Rehabilitation Group, Scottish Division, Royal College of Psychiatrists. We gratefully acknowledge the help of the many professionals who helped supply information and Dr J. G. Greene for statistical advice. 


\section{References}

Department of Health and Social Security (1975) Better Services for the Mentally Ill. London: HMSO.

Her Majesty's Stationery Office (1989) Caring for People. Community Care in the Next Decade and Beyond. London: HMSO

McCreadie, R. G., Affleck, J. W. \& Robinson, A. D. (1985) The Scottish survey of psychiatric rehabilitation and support services. British Journal of Psychiatry, 147, 289-294.
Royal College of Psychintrists (1991) Good Medical Practice in Aftercare of Potentially Violent and Vulnerable Patients discharged from Inpatient Psychiatric Treatment. London: Royal College of Psychiatrists.

SCOTTISH OFFICE (1991) Development of Community Care. Consultation Paper No. 6. Draft Guidance on Care Programmes for People with a Mental illness (including Dementia). Edinburgh: Scottish Office.

\section{Eastenders on the South Coast}

\section{Richard Duffett, Registrar, The Royal London Hospital; and Claire Lawton, Consultant Psychiatrist for the Elderly, The Royal London Hospital, Bow, London E3}

In spite of the moves over the last 20 years towards community care, there remain substantial numbers of elderly people with both physical and mental illness who require residential, nursing home and hospital care. There is evidence to suggest that health service provision of long term care for the mentally ill has been, and continues to be, reduced. In addition there has been reduction in beds for long term care by geriatric physicians and while the nursing home and residential care sectors have expanded, this expansion has been entirely within the 'independent' private and voluntary sector, with considerable contraction of local authority provision. Representations have been made about this to the Old Age Section of the Royal College of Psychiatrists and they have reported on this (Benbow \& Jolley, 1992). Concern has not been confined to the profession. Over the last year, there has been considerable media publicity about the long term care of elderly people in institutions. Some of this has been very critical [Panorama, 20.1.92] and has provoked debate on the pages of the national papers.

There are particular problems in inner city areas where there are few private and voluntary homes. This is the case in Tower Hamlets where our local facilities have been reduced by at least 200 places in the last five years. Tower Hamlets is a deprived area of inner London with high Jarman Indices (Jarman, 1981). The plight of elderly Eastenders in the community was well described by Dr David Widgery (1991).
Tower Hamlets has a population of 160,000 in a small densely populated area, of whom 23,050 are over 65 years of age. There is a large immigrant population, particularly represented among the young. Old age psychiatry up until the period studied had 48 medium and long stay beds. Since 1990, 17 of these beds have been used increasingly for short term and respite care and assessment. There has been no change to the functional beds. Geriatric services are concentrated at Mile End Hospital where there are 121 acute and 46 long stay beds. Within the borough there is one private nursing home, one 40 bedded EMI (elderly mentally infirm) unit and approximately 190 part III beds.

In these constrained times, health and social services in areas such as our own have had no option but to look outside the district for alternative residential care of all types. This has not evolved as coherent strategy but has been driven by need. We therefore decided to look at the consequences of this increased use of private and voluntary homes outside our borough. Although we did not formally assess the quality of the homes used, they were all approved by social services and visited by one or another member of the multidisciplinary team and by family or carers where possible. They were all found to be satisfactory at the time of placement. Other workers have found the quality of the environment in private homes reasonably good (Perkins et al, 1989). 